\title{
Looking for the key to preservation of fossil marine vertebrates in the Pisco Formation of Peru: new insights from a small dolphin skeleton
}

\author{
*Anna Gioncada ${ }^{1}$, Karen Gariboldi ${ }^{1}$, Alberto Collareta ${ }^{1,2}$, Claudio Di Celma ${ }^{3}$, Giulia Bosio ${ }^{4}$, \\ Elisa Malinverno ${ }^{4}$, Olivier Lambert ${ }^{5}$, Jennifer Pike $^{6}$, Mario Urbina ${ }^{7}$, Giovanni Bianucci ${ }^{1}$
}

\author{
${ }^{1}$ Dipartimento di Scienze della Terra, Università di Pisa, via Santa Maria 53, 56126 Pisa, Italy. \\ anna.gioncada@unipi.it; karen.gariboldi@for.unipi.it; giovanni.bianucci@unipi.it \\ ${ }^{2}$ Dottorato Regionale in Scienze della Terra Pegaso, via Santa Maria 53, 56126 Pisa, Italy. \\ alberto.collareta@for.unipi.it \\ ${ }^{3}$ Scuola di Scienze e Tecnologie, Università di Camerino, via Gentile III da Varano, 62032 Camerino, Italy. \\ claudio.dicelma@unicam.it \\ ${ }^{4}$ Dipartimento di Scienze dell'Ambiente e della Terra, Università di Milano-Bicocca, Piazza della Scienza 4, Milan, Italy. \\ giulia.bosio.giulia@gmail.com; elisa.malinverno@unimib.it \\ ${ }^{5}$ Institut Royal des Sciences Naturelles de Belgique, D.O. Terre et Histoire de la Vie, rue Vautier, 29, B-1000 Brussels, Belgium. \\ olivier.lambert@naturalsciences.be \\ ${ }^{6}$ School of Earth and Ocean Sciences, Cardiff University, Main Building, Park Place, Cardiff, CF10 3YE, UK. \\ pikej@cardiff.ac.uk \\ ${ }^{7}$ Departamento de Paleontologia de Vertebrados, Museo de Historia Natural de la Universidad Nacional Mayor de San Marcos, \\ Avda. Arenales 1256, Lima 14, Perú. \\ mariourbina01@hotmail.com
}

*Corresponding author: anna.gioncada@unipi.it

\begin{abstract}
The upper Neogene Pisco Formation of Peru is known worldwide as one of the most significant Cenozoic marine vertebrate Konservatt-Lagerstätten, even featuring cetacean specimens that retain remains of soft tissues or stomach contents. Previous works showed that biomediated precipitation of dolomite concretions around large-sized decaying carcasses was one of the most relevant processes responsible for exceptional fossil preservation. In turn, little is known about the modes of fossilization of well-preserved small-sized vertebrates, which are rather common in the Pisco Formation, but mostly do not exhibit dolomite concretions. We report on a cetacean specimen, identified as belonging to the extinct short-snouted, small dolphin species Brachydelphis mazeasi (Pontoporiidae), preserved within a late Miocene sandy deposit at the site of Pampa Corre Viento. This specimen consists of a moderately disarticulated partial skeleton exhibiting well-mineralized bones; it is not enclosed within a dolomite concretion, being however delimited by an evident dark boundary in the host sediment. Scanning electron microscopy and microanalytical investigations identify Mn-oxides and apatite as early diagenetic minerals around the skeleton. We argue that a rapid burial of the specimen was pivotal for the preservation of the bones, and allowed the early establishment of anoxic processes for degradation of organic matter. Coupled with availability of $\mathrm{P}$ in porewater, the reducing conditions and the lowered $\mathrm{pH}$ allowed precipitation of Ca-phosphate while increasing Mn solubility close to the pontoporiid carcass. Mn-oxides precipitated at the redox boundary, the latter defining the outer edge of the volume of sediment affected by altered chemical conditions due to the decaying processes. The permeability of the sediment and the small size of the carcass were possible factors unfavorable to extensive sulfate reduction, thus preventing the formation of a dolomite concretion and allowing bone phosphatization. This record emphasizes the role of conditions favorable to bone mineralization in absence of an isolating carbonate concretion, in cases of high quality preservation of small-sized vertebrates observed in the Pisco Formation. The observation of patterns in the distribution of diagenetic minerals in the sediment enclosing vertebrate remains without, or with limited carbonate concretions provides insights into early taphonomic processes.
\end{abstract}


RESUMEN. Buscando la clave para la preservación de los vertebrados marinos fósiles en la Formación Pisco, (Perú): nuevos indicios a partir de un pequeño esqueleto de delfín. La Formación Pisco de Perú, del Neógeno tardío, es conocida a nivel mundial como uno de los principales Konservatt-Lagerstätten, donde se preservan vertebrados marinos, presentando incluso, restos de tejidos blandos y contenido estomacal de los fósiles. Trabajos previos han demostrado que las precipitaciones de dolomita, mediante actividad biológica, alrededor de grandes cadáveres en descomposición, fue uno de los procesos principales en la preservación de estos fósiles. Sin embargo, son poco conocidos los procesos de fosilización de los vertebrados de pequeño tamaño, los cuales se encuentran bien conservados y son bastante comunes en la Formación Pisco, pero en su mayoría no muestran concreciones de dolomita. En este estudio presentamos un pequeño espécimen de cetáceo, perteneciente a la especie extinta de nariz corta Brachydelphis mazeasi (Pontoporiidae), conservado dentro de un depósito arenoso del Mioceno tardío, en el sitio de Pampa Corre Viento. Este espécimen consiste de un esqueleto parcialmente desarticulado que exhibe una buena mineralización, no se encuentra dentro de una concreción de dolomita, pero el sedimento de su en torno posee una coloración negra bien evidenciada. Mediante microscopía electrónica se han identificado óxidos de Mn y apatito alrededor del esqueleto como minerales producto de diagénesis temprana. Argumentamos que un enterramiento rápido del espécimen fue fundamental para la preservación de los huesos, y permitió el pronto establecimiento de condiciones anóxicas para la degradación de la materia orgánica. La disponibilidad de $\mathrm{P}$ en el agua de poro, las condiciones reductoras y disminución del $\mathrm{pH}$, permitieron la precipitación de Ca-fosfato, a la vez que aumentaba la solubilidad de Mn cerca de la carcasa del pontoporiido. Los oxidos de Mn precipitaron en el límite redox y definieron el borde externo del sedimento químicamente afectado por los procesos de descomposición. La permeabilidad del sedimento y el tamaño pequeño de la carcasa fueron posiblemente factores desfavorables para la reducción de sulfato, evitando así la formación de una concreción de dolomita y permitiendo la fosfatación ósea. Este registro enfatiza el papel de las condiciones favorables para la mineralización ósea en ausencia de la formación de una concreción aislante de carbonato, en casos de preservación de alta calidad de vertebrados de pequeño tamaño de la Formación Pisco. La observación de patrones de distribución de minerales diagenéticos en el sedimento puede dar una idea acerca de los procesos tafonómicos tempranos.

Palabras clave: Vertebrados marinos, Tafonomía, Formación Pisco, Fosilización, Fosfatación, Diagénesis temprana.

\section{Introduction}

Cropping out along the southern coast of Peru from Pisco to Yauca, the Pisco Formation is a late Neogene, shallow-marine sedimentary unit, which is known worldwide for its outstanding paleontological content. In particular, the record of fossil marine vertebrates of the Pisco Formation is exceptional in terms of abundance of specimens, taxonomic diversity, ecomorphological disparity, and quality of preservation. Examples of remarkably preserved fossil remains featured in the Pisco Formation include phosphatized baleen plates and bristles of mysticete whales (Pilleri and Pilleri, 1989; Brand et al., 2004; Esperante et al., 2008; Bisconti, 2012; Gioncada et al., 2016; Marx and Kohno, 2016; Marx et al., 2017), stomach contents and regurgitations of cetaceans and sharks (Collareta et al., 2015, 2017; Lambert et al., 2015), and articulated skeletons of cartilaginous fish (Ehret et al., 2009, 2012; Collareta et al., 2017). Consequently, the Pisco Formation is now recognized as one of the most important Cenozoic marine Fossil-Lagerstätten worldwide (Esperante et al., 2015; Collareta et al., 2015, 2017; Gariboldi et al., 2015; Bianucci et al., 2016a, b; Gioncada et al., 2016). Such an outstanding accumulation of fossil vertebrates is currently regarded as the result of a complex interplay of different biotic and abiotic factors and processes, which concurred in creating an environmental setting where post-mortem preservation processes were, locally and at times, greatly facilitated. In particular, the widespread presence of dolomite concretions enclosing many fossil vertebrates of the Pisco Formation has been recently recognized. The formation of mineral concretions during early diagenesis as a consequence of biomediated processes related to organic matter decay has been described elsewhere (McCoy et al., 2015; Yoshida et al., 2015). In the Pisco Formation, early precipitation of dolomite around vertebrate carcasses, although not always present, has been pointed out for its major contribution in allowing the preservation of complete and articulated skeletons, delicate anatomical structures, and even soft organic tissues (Gariboldi et al., 2015; Gioncada et al., 2016, 2018). Field evidence and petrographic observations indicate that this precipitation process affected especially large vertebrate carcasses (e.g., large-sized baleen whales), whereas it appears to have been less important (up to almost negligible) in correspondence 
of smaller carcasses (e.g., small-sized delphinidans and pinnipeds) whose often well-preserved remains constitute a large part of the fossil assemblages of the Pisco Formation (Gariboldi et al., 2015; Bianucci et al., 2016a, b; Di Celma et al., 2017). Consequently, providing a detailed and integrated characterization of the modes of fossilization of small-sized (i.e., less than $2.5 \mathrm{~m}$ in total length) vertebrates preserved in absence of dolomite concretions is pivotal for understanding the genesis of the Pisco Formation Fossil-Lagerstätte. For this purpose, we investigated a well-preserved skeleton of a small pontoporiid dolphin from Pampa Corre Viento, a locality in the Ica Desert where upper Miocene beds of the Pisco Formation are exposed. This specimen is kept in the Museo de Historia Natural de la Universidad Nacional Mayor de San Marcos of Lima, Peru (hereinafter: MUSM) with accession number MUSM 887. Although this specimen is not enclosed within a dolomite concretion, it is surrounded by an evident dark boundary, suggesting that the processes involved in fossilization left their traces in the form of diagenetic minerals around the cetacean skeleton. Examples of similar dark boundaries around remains of larger-sized vertebrates have been observed in the field within the Pisco Formation at the localities of Cerro Los Quesos and Cerro Colorado (Gariboldi et al., 2015). With the aim of shedding light on the fossilization processes that affected well-preserved skeletons of small-sized vertebrates in the Pisco Formation, we undertook a taphonomic, petrographic, and mineralogical study of MUSM 887 and of its "nodule", thus adding a new piece to the comprehension of this renowned Fossil-Lagerstätte.

\section{Geological and stratigraphic background}

From a tectonic viewpoint, the Peruvian margin is recognized as a long-lived convergent margin with the oceanic Nazca/Farallon Plate subducting approximately eastward below the western margin of the South America plate, in the Peru-Chile Trench. The subduction of normal oceanic crust and collision of the aseismic Nazca Ridge beneath this part of the forearc have been associated with a wide range of effects on the overriding continent, including longterm subsidence driven by basal tectonic erosion and the development of a composite transform-convergent margin dominated by extensional and strike-slip tectonic activity (Kulm et al., 1982; Dunbar et al.,
1990; Clift et al., 2003; Hampel et al., 2004, León et al., 2008; Zúñiga-Rivero et al., 2010). According to Thornburg and Kulm (1981), two trench-parallel structural highs were formed on the continental shelf and upper slope of the Peruvian margin during Late Cretaceous-early Paleogene time, namely the Outer Shelf High and the Upper Slope Ridge. These two ridges subdivided the Peruvian offshore into a series of basins, which may be separated into an inner set of shelf basins and a seaward set of slope basins. The East Pisco Basin in southern Peru formed in the forearc between $13^{\circ}$ and $15^{\circ} \mathrm{S}$ and is separated from the adjacent West Pisco Basin, which is located on the slope, by the Outer Shelf basement high. The sedimentary fill of the East Pisco Basin includes the middle Eocene Caballas Formation, the middle to upper Eocene Paracas Group, the uppermost Eocene to lower Oligocene Otuma Formation, the uppermost Oligocene to middle Miocene Chilcatay Formation, and the upper Miocene to Pliocene Pisco Formation (Dunbar et al., 1990; DeVries, 1998). These formations are bounded by regionally beveling, conglomeratemantled unconformities that are locally accompanied by angular discordances.

Due to onlap and loss of successively younger beds at the base, in the study area the Pisco Formation forms a northeastward-thinning wedge which is little deformed and with a general dip of strata between $4^{\circ}$ and $7^{\circ}$ to the northeast. Strata of the Pisco Formation can be subdivided into three allomembers or depositional sequences (designated P0, P1 and P2 from oldest to youngest) that are tens to hundreds of meters thick and broadly fining-upward in aspect (Di Celma et al., 2016a, b, 2017, 2018a). A typical sequence comprises a lower, sandstone-rich nearshore succession passing upsection, through intermediary facies, into a monotonous succession dominated by diatomaceous mudstones. The allomember boundaries are taken at intraformational erosion surfaces of basinal extent and indicate abrupt seaward shift in facies.

The excellent agreement between biostratigraphic data and a few well-constrained ${ }^{40} \mathrm{Ar} /{ }^{39} \mathrm{Ar}$ radiometric ages from volcanic ash layers provides useful constraints on the depositional age of the three Pisco sequences. At present, due to the lack of direct biostratigraphic and radiometric data, the age of $\mathrm{P} 0$ is constrained between by the age of the upper portion of the Chilcatay Formation $(18.02 \pm 0.07 \mathrm{Ma}$ from ${ }^{40} \mathrm{Ar} /{ }^{39} \mathrm{Ar}$ radiometric ages on a volcanic ash layer from the top of the Chilcatay strata at Cerro 
Submarino, Di Celma et al., 2018b) and the onset of deposition of the overlying P1 allomember strata at Cerro Colorado (dated between 9.5 and $9.10 \pm 0.04 \mathrm{Ma}$ by means of diatom biostratigraphy and ${ }^{40} \mathrm{Ar} /{ }^{39} \mathrm{Ar}$ dating); the base of $\mathrm{P} 2$ allomember is younger than 8.5 Ma (Gariboldi et al., 2017).

The cetacean specimen described herein was found by one of the authors (M.U.) at Pampa Corre Viento (indicative geographic coordinates: $14^{\circ} 27^{\prime} \mathrm{S}$, $75^{\circ} 45^{\prime} \mathrm{W}$ ), a locality $c a .40 \mathrm{~km}$ south of Ica and about $7.5 \mathrm{~km}$ north-northeast of Cerro Los Quesos (a fossil marine vertebrate-rich locality of the Pisco Formation, Bianucci et al., 2016a) (Fig. 1A). The sediment succession exposed at Corre Viento belongs to the lower portion of the $\mathrm{P} 2$ depositional sequence of the Pisco Formation and, therefore, an age of less than 8.5 Ma can be inferred for the specimen described in this study (Fig. 1B).

\section{Results}

\subsection{Description of MUSM 887}

The fossil specimen consists of an almost complete skeleton, which is partially articulated and partially enclosed in two distinct blocks of indurated sediment (Fig. 2). The main block contains the cranium, both mandibles, parts of the pectoral girdle and forelimbs, an anterior section of the vertebral column, and parts of the rib cage. The short-snouted cranium is complete, lying in left dorsolateral view, and the mandibles are substantially preserved in situ, only slightly shifted with respect to each other at the level of the mandibular symphysis. Both the maxilla and the mandibles support several sharp, tiny teeth. Posterior to the skull, a well-articulated segment of the vertebral column is preserved, with the atlas still connected to the skull (via the right occipital condyle) and to the axis. The other cervical vertebrae are strongly anteroposteriorly flattened and possibly fused to each other; they are followed in anatomic connection by at least the first thoracic vertebra. The rib cage is collapsed, and the ribs, most of which are complete, rest horizontally around and above the articulated vertebrae. Among ribs, a detached vertebral epiphysis has been detected. The almost complete left scapula is superimposed on some ribs and, partially, on the anteriormost section of the vertebral column and on the first sternebra (i.e., the manubrium). Two ribs lying under the left scapula have induced on the latter two systems of load fracturing. The left humerus is still articulated to the corresponding scapula. Additionally, two isolated fragmentary vertebrae (including a posterior thoracic) have been identified close to the collapsed remains of the rib cage.

The second block contains thirteen fully articulated lumbar to caudal vertebrae, some of which (the anteriormost) being covered in part by the fragments of at least five ribs (Appendix Fig. 1). Moreover, a single isolated vertebral epiphysis has been detected.

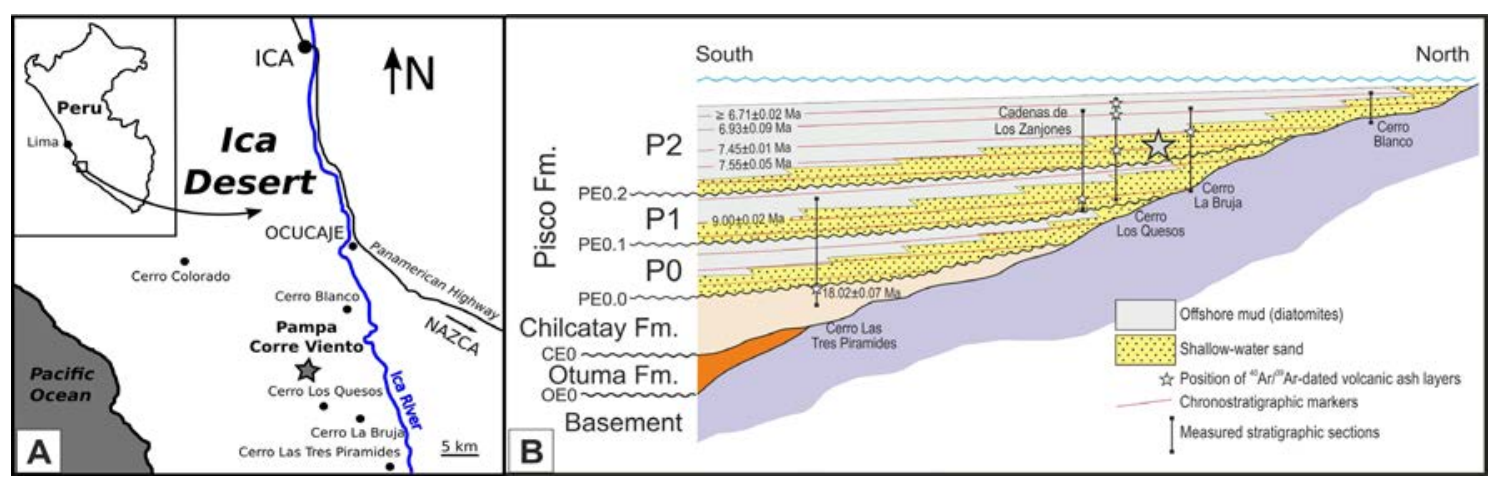

FIG. 1. A. Location of Corre Viento, the fossil-bearing locality where the skeleton of the small dolphin Brachydelphis mazeasi MUSM 887 was found, in the Ica Desert (Peru); B. Schematic, dip-oriented allostratigraphic diagram for the Pisco Formation and the lower Chilcatay and Otuma Formations (not to scale), showing the indicative stratigraphic position of the strata of the late Miocene P2 sequence exposed at Corre Viento. The Pisco Formation exhibits pronounced thinning to the northeast, with the allomembers onlapping onto the basal composite surface PE0.0 and arranged in a retrogradational pattern, progressively offset to northeast. Figure 1B modified from Di Celma et al. (2017). 


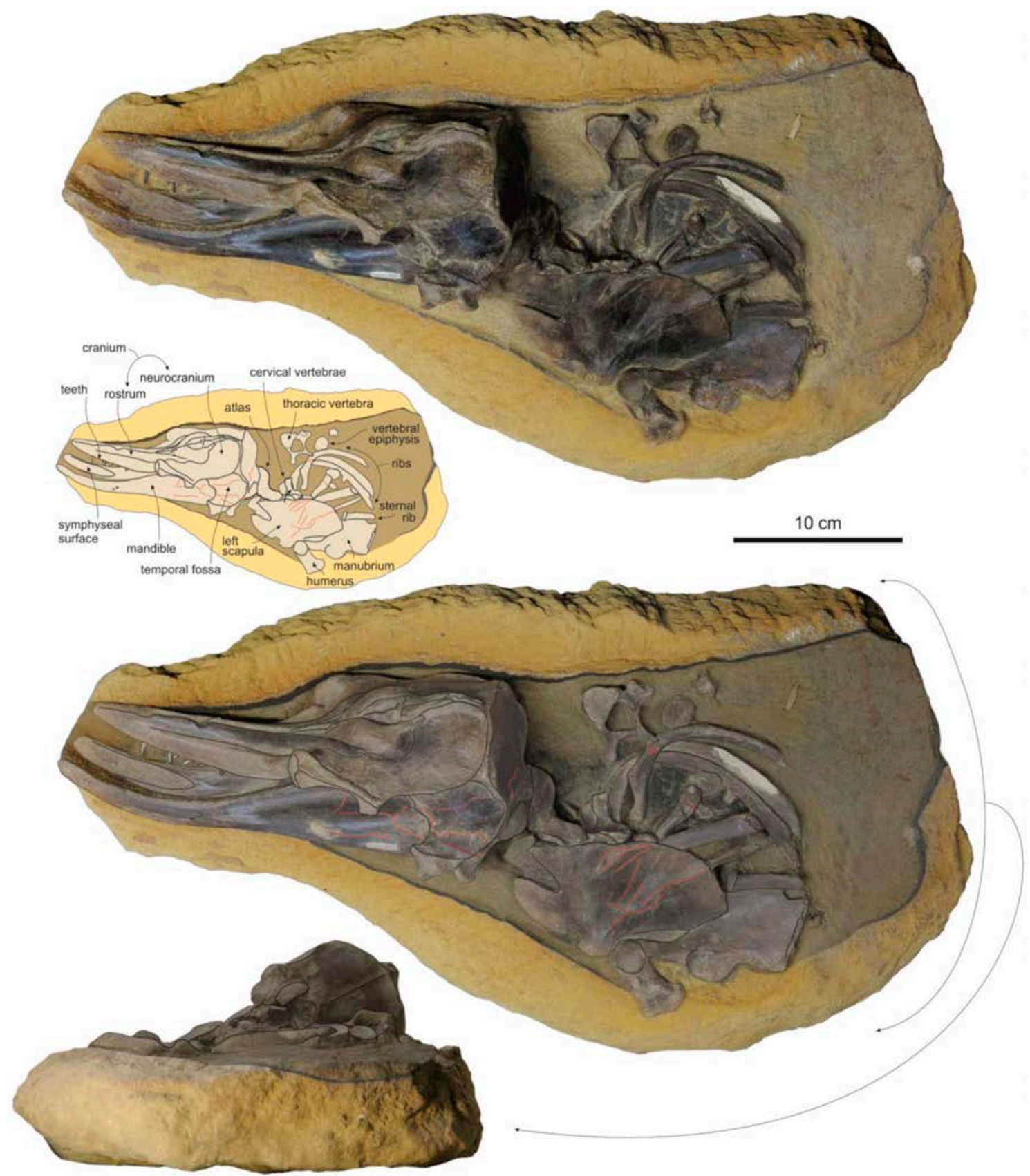

FIG. 2. The block containing the remains of the skull, bony thorax, and left forelimb of the small dolphin Brachydelphis mazeasi MUSM 887, with corresponding line drawings indicating the different elements preserved.

At a variable distance ranging from $c a .1$ to $10 \mathrm{~cm}$ of the pontoporiid bones, a thin but conspicuous layer of blackish, stiffened sediment runs all around the cetacean remains, completely wrapping the partial skeleton (Fig. 2).

\subsection{Systematic attribution of MUSM 887}

Based on the observation of i) anteroposteriorly elongated nasals; ii) a proportionally low skull vertex; iii) the presence of maxillary crests on the antorbital 
processes; iv) the presence of premaxillary eminences (i.e., inflated premaxillary sac fossae region), this specimen is unambiguously attributed to the family Pontoporiidae (e.g., De Muizon, 1988; Lambert and Post, 2005). Due to the observation of i) a dorsoventrally and transversely expanded lacrimal, which constitutes the major part of the enlarged antorbital process; ii) a deep and narrow antorbital notch, MUSM 887 is assigned to the genus Brachydelphis De Muizon, 1988, as redefined by Lambert and De Muizon (2013). This attribution is further corroborated by the observation of a weak transverse constriction of the premaxilla at the level of the base of the rostrum, a character observed in Brachydelphis, but not in the other pontoporiid genera known to date (Gutstein et al., 2009; Lambert and De Muizon, 2013). Brachydelphis is a late Miocene pontoporiid genus that is rather common both in the Pisco Formation and in the roughly coeval Bahía Inglesa Formation of northern Chile (De Muizon, 1988; Gutstein et al., 2008, 2009; Bianucci et al., 2016b; Di Celma et al., 2017). On the basis of i) the short, triangular, and upwardly projecting rostrum; ii) the narrow separation between the maxillae across the skull vertex, MUSM 887 can be assigned to Brachydelphis mazeasi De Muizon, 1988 rather than to the other, longer-snouted species $B$. jahuayensis Lambert and De Muizon, 2013. For what concerns the Pisco Formation, specimens of $B$. mazeasi were found in the stratal package of the $\mathrm{P} 1$ sequence (notably including the Tortonian deposits that form the lowest part of the sedimentary succession exposed at Cerro Colorado, referred to by Di Celma et al., 2016b as the "lower allomember") and the basal beds of the P2 sequence (which in turn correspond to the "Cerro La Bruja vertebrate level" of De Muizon and DeVries, 1985 and De Muizon, 1988) (Bianucci et al., 2016b; Di Celma et al., 2017). Based on comparison with extant Pontoporia, the total body length of the Brachydelphis mazeasi specimen MUSM 887 can be estimated at about $175 \mathrm{~cm}$; therefore, it is here regarded as wellrepresentative of those small-sized vertebrates (shorter than $2.5 \mathrm{~m}$ in total length, as defined previously) whose fossilized skeletons comprise a large fraction of the marine vertebrate assemblages of the Pisco Formation.

\subsection{Petrography and chemistry of the MUSM 887 bones}

The bony remains have been firstly inspected at the MUSM with a hand lens. The compact tissue of the bone is hard and has a dark amber color (Fig. 2), the external surface being blackened by late $\mathrm{Mn}$ patinae, while the trabecular tissue exhibits late gypsum/anhydrite crystals partially infilling the intertrabecular cavities. Macroscopically, no traces of abrasion were observed and fragmentation is scarce.

A $1 \mathrm{~cm}$-sized fragment of rib (consisting of both cortical and spongy bone) was broken in smaller fragments for stereoscopic observation and then mounted in resin, sectioned, and polished for subsequent analyses (for analytical methods see Appendix). Reflected-light optical microscopy and scanning electron microscopy-backscattered electron imaging (SEM-BSEI) indicates a wellpreserved compact bone, without evidence of low density zones, replacement, or microborings, and without any carbonate concretion (Fig. 3A). The composition of the bone tissue is homogeneous and corresponds to calcium phosphate. Electron microprobe analyses (reported in Table 1) indicate a chemistry corresponding to fluorapatite, with $\mathrm{Ca} / \mathrm{P}$ ratio of 1.65-1.79 and $\mathrm{MgO}$ and $\mathrm{Na}_{2} \mathrm{O}$ both averaging $1.1 \mathrm{wt} \%, \mathrm{SO}_{3} 3.3 \mathrm{wt} \%$, and $\mathrm{FeO}$ around $0.1 \mathrm{wt} \%$. Analytical totals for the electron probe analyses are in the range $90-93 \mathrm{wt} \%$.

\subsection{Petrography and mineralogy of the sediment enclosing MUSM 887}

Two samples of the sediment enclosing MUSM 887 were collected: the first from nearby the bones and the latter from the dark boundary layer under the specimen (Fig. 2). Both samples are made of siliciclastic sand, consisting of terrigenous rock fragments and crystals (plagioclase, ilmenite, chlorite, quartz, and amphibole), volcanogenic glassy clasts, and minor biogenic (diatoms) components. The sediment is yellowish close to the bones and reddish out of the black boundary layer.

Observations under reflected-light optical microscope and SEM-both secondary electron (SE) and back-scattered electron (BSE) imaging - reveal that the black layer (Fig. 3B, C, D) consists of Mn oxides cementing the sediment for an average thickness of 3-4 $\mathrm{mm}$ and also filling the fine pores of diatom frustules. The upper edge of the Mn-rich layer (i.e., its transition to the yellow sediment hosting the bones) is irregular, but sharp and well-defined, whereas its lower edge (i.e., its transition to the reddish sediment far from the cetacean remains) is gradual. 
Between the Mn-rich layer and the skeleton, calcium phosphate rods or needles about 2-4 $\mu \mathrm{m}$ in length and smaller grains permeate the sediment (Fig. 3E). Their small size prevented from obtaining spectra on single crystals by means of Energy
Dispersive X-ray Spectrometry (EDS); however, the calcium phosphate composition was determined collecting several spectra on raster areas measuring about $5 \times 5 \mu \mathrm{m}$ (Fig. 4). Their P-Ca composition, small size, and occurrence suggest a mineral of
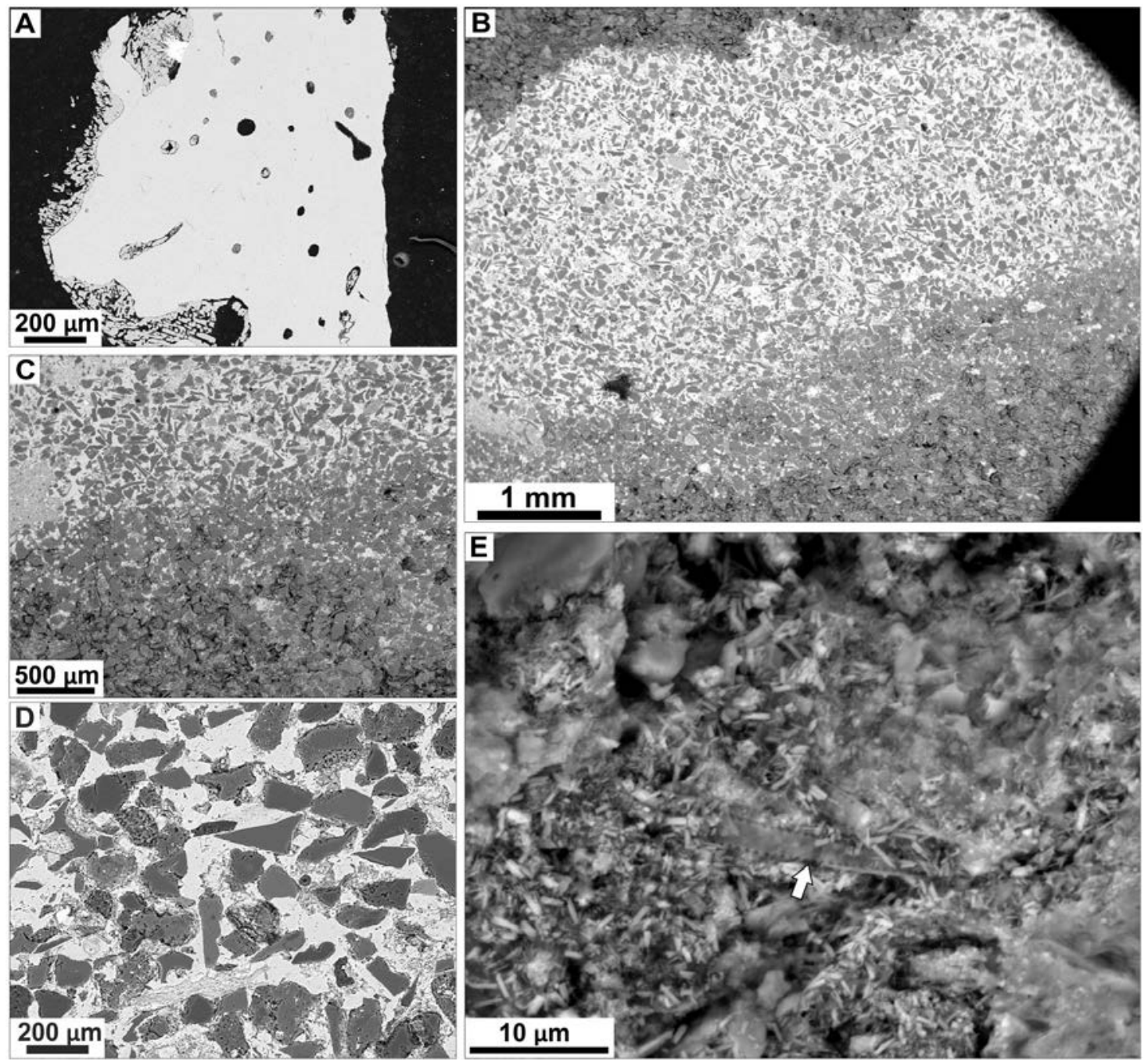

FIG. 3. A. SEM-BSE detail of a fragment of the rib of Brachydelphis mazeasi specimen MUSM 887 in transverse section. The left margin of the sample represents the inner part the rib, consisting of cancellous tissue and exhibiting late gypsum/anhydrite crystals within the pores of the bone. The cortical tissue shows neither microborings, nor other evidence of erosion; B. SEMBSE overview of the black layer observed in the sediment enclosing MUSM 887. The yellow sediment close to the bones corresponds to the dark-gray domain on the upper portion of the sample. The Mn layer corresponds to the wide whitish area in the central portion of the sample, in which the white cement consists of Mn oxide minerals. The boundary between the Mn layer and the yellow layer is sharp and well-defined. The red sediment corresponds to the light-gray domain in the lower portion of the sample. The boundary between the Mn layer and the red sediment is not well-defined; $\mathbf{C}$. Detail of the gradual boundary between the Mn layer and the surrounding red sediment; D. Close-up of the Mn layer: Mn oxides cement terrigenous sand particles; E. SEM-SE image of pervasive authigenic apatite micro-crystals within the yellowish sediment. A diatom specimen (referred to Thalassionema nitzschioides) is visible in the centre of the panel (arrow). 
TABLE 1. ELECTRON MICROPROBE QUANTITATIVE CHEMICAL ANALYSES OF THE CORTICAL BONE TISSUE OF MUSM 887. SEE APPENDIX FOR ANALYTICAL DETAILS.

\begin{tabular}{lrrrrrrrrrrr}
\hline & $\mathbf{1}$ & \multicolumn{1}{c}{$\mathbf{2}$} & $\mathbf{3}$ & \multicolumn{1}{c}{$\mathbf{4}$} & \multicolumn{1}{c}{$\mathbf{5}$} & $\mathbf{6}$ & $\mathbf{7}$ & $\mathbf{8}$ & $\mathbf{9}$ & $\begin{array}{c}\text { mean } \\
{[9]}\end{array}$ & SD \\
\hline $\mathrm{SiO}_{2}$ & $\mathrm{bdl}$ & 0.02 & 0.01 & 0.01 & 0.01 & 0.01 & bdl & bdl & 0.02 & 0.01 & 0.01 \\
$\mathrm{Fe}_{2} \mathrm{O}_{3} \mathrm{t}$ & 0.09 & 0.14 & 0.07 & 0.14 & 0.08 & 0.10 & 0.11 & 0.10 & 0.14 & 0.11 & 0.03 \\
$\mathrm{MnO}$ & 0.09 & 0.09 & 0.10 & 0.08 & 0.11 & 0.13 & 0.08 & 0.09 & 0.08 & 0.09 & 0.02 \\
$\mathrm{MgO}$ & 1.24 & 1.20 & 1.02 & 1.11 & 1.11 & 0.97 & 1.06 & 1.08 & 1.02 & 1.09 & 0.09 \\
$\mathrm{CaO}$ & 46.18 & 47.52 & 47.81 & 48.59 & 47.94 & 47.59 & 48.50 & 48.29 & 48.88 & 47.92 & 0.80 \\
$\mathrm{Na} \mathrm{O}_{2}$ & 0.98 & 1.12 & 1.21 & 1.18 & 1.08 & 1.05 & 1.11 & 1.12 & 1.07 & 1.10 & 0.07 \\
$\mathrm{P}_{2} \mathrm{O}_{5}$ & 35.41 & 35.04 & 35.65 & 34.82 & 34.19 & 33.70 & 34.66 & 34.60 & 34.61 & 34.74 & 0.59 \\
$\mathrm{SrO}$ & 0.07 & 0.24 & 0.13 & 0.15 & 0.11 & 0.16 & 0.11 & 0.06 & 0.17 & 0.13 & 0.05 \\
$\mathrm{SO}$ & 3.20 & 3.36 & 3.37 & 3.44 & 3.34 & 3.36 & 3.24 & 3.32 & 3.21 & 3.31 & 0.08 \\
$\mathrm{~F}$ & 2.67 & 2.47 & 3.01 & 3.98 & 3.32 & 4.04 & 3.38 & 3.71 & 4.01 & 3.40 & 0.59 \\
$\mathrm{Cl}$ & 0.15 & 0.10 & 0.18 & 0.13 & 0.09 & 0.09 & 0.13 & 0.11 & 0.11 & 0.12 & 0.03 \\
$\mathrm{sum}$ & 90.07 & 91.30 & 92.56 & 93.62 & 91.37 & 91.19 & 92.36 & 92.48 & 93.31 & 92.03 & 2.36 \\
$\mathrm{Ca} / \mathrm{P}$ & 1.65 & 1.72 & 1.70 & 1.77 & 1.77 & 1.79 & 1.77 & 1.77 & 1.79 & 1.75 & 0.05 \\
\hline
\end{tabular}

All values in $\mathrm{wt} \%$ except for the $\mathrm{Ca} / \mathrm{P}$ atomic ratios. All $\mathrm{Fe}$ as $\mathrm{Fe}_{2} \mathrm{O}_{3}$. SD: standard deviation; bdl: below detection limit.

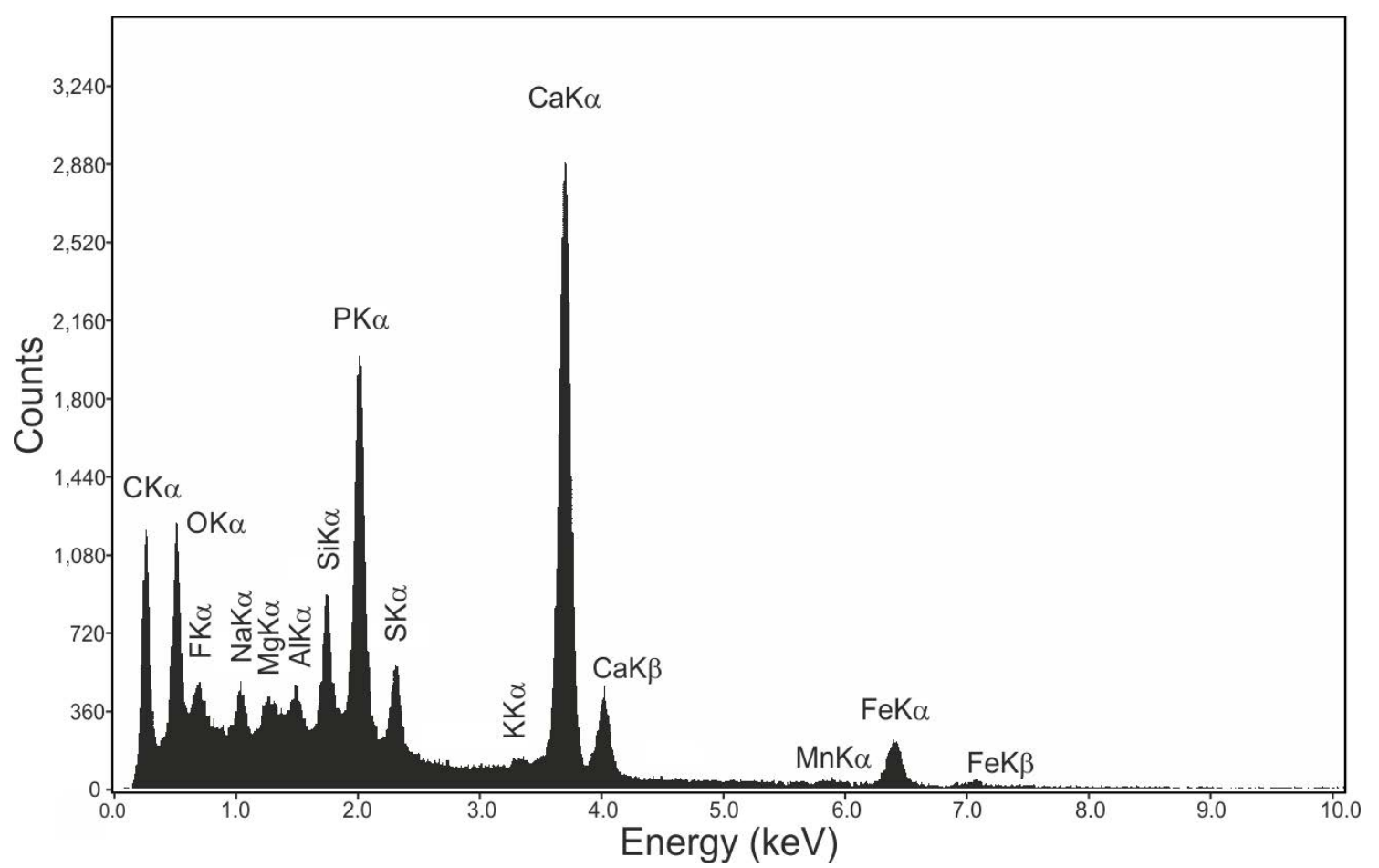

FIG. 4. Energy-dispersive X-ray spectroscopy (EDS) spectrum of the apatite crystals shown in figure $3 \mathrm{E}(5 \times 5 \mu \mathrm{m}$ raster area). 
the apatite group and a diagenetic (rather than clastic) origin.

Below the Mn layer, Fe-oxides or hydroxides are abundant in the matrix, whereas calcium phosphate crystallites are absent.

X-rays Powder Diffraction data, aimed at detecting the presence of carbonate phases in the sediment, did not reveal calcite or dolomite either above or below the black Mn-rich layer.

\subsection{A field example of Mn layer under a fossil marine vertebrate in the Pisco Formation}

In several cases, the dolomite concretions enclosing fossil marine vertebrate remains of the Pisco Formation were observed being delimited outwards by a dark boundary, with a characteristic sequence of colors corresponding to concentrations of $\mathrm{Mn}$ and $\mathrm{Fe}$ (Gariboldi et al., 2015). For one of these Mn layers, sampled at Cerro Los Quesos in correspondence of a balaenopteroid (rorqual) baleen whale specimen with a moderately developed dolomite concretion (Fig. 5A, B; specimen M58 in Bianucci et al., 2016a), EDS (electron dispersion spectroscopy) elemental maps were collected and overlaid on SEM electron images (Fig. 5; Appendix Fig. 2). Single element maps of Al, Ca, $\mathrm{Fe}, \mathrm{Mg}, \mathrm{Mn}, \mathrm{P}, \mathrm{S}$ and Si have been run for the dark boundary layer and the overlying and underlying sediments; additionally, four combined maps have been generated: $\mathrm{Ca}+\mathrm{P}, \mathrm{Fe}+\mathrm{Mn}, \mathrm{Fe}+\mathrm{Mn}+\mathrm{Ca}+\mathrm{P}$, and $\mathrm{Mg}+\mathrm{Ca}+\mathrm{Mn}+\mathrm{Fe}+\mathrm{Si}+\mathrm{P}+\mathrm{S}$. This latter map summarizes the distribution of all the elements mapped individually and shows the BSE image of the slide on the background (Fig. 5C).

Maps of $\mathrm{Ca}, \mathrm{P}$, and $\mathrm{Mn}$ reveal a concentration of these elements in defined millimetric layers. $\mathrm{Ca}$ is scattered in submillimetric spots all around the slide and concentrated in a layer at about 3.5$5 \mathrm{~mm}$ from the top of the slide where $\mathrm{P}$, also, is concentrated (Fig. 5D, E); the scattered Ca spots are easily interpreted as gypsum, comparing the Ca map with the S map (Appendix Fig. 2), while the superposition of the $\mathrm{Ca}$ and $\mathrm{P}$ maps (Fig. 5F) suggests that the highlighted layer is a Ca-phosphate layer. The Mn map (Fig. 5G) highlights that this element is concentrated in a discontinuous layer, 1.0 to $2.5 \mathrm{~mm}$ thick, inside and roughly parallel to that of the apatite layer, from which it is separated by $c a .1 .0$ to $c a .2 .5 \mathrm{~mm}$ of sediment (Fig. 5C).

\section{Discussion}

\subsection{Deposition, burial and mineralization of the bones}

The overall organization of MUSM 887 in two distinct blocks, each of which is comprised of anatomically coherent and rather articulated bones, suggests an early burial of the carcass by soft sediment, followed by gravitational collapse of the body due to decay-related fluidization of the soft tissues, and consequent loss of connectivity of the skeletal elements (e.g., Reisdorf et al., 2014). Moreover, a moderate degree of deformation and bone displacement during diagenetic compaction of the host sediment (e.g., Reisdorf et al., 2012) cannot be excluded, as possibly supported by the observation of load fracturing on the left scapula of MUSM 887 (see above). Although early burial due to the action of bottom currents (possibly concurring to bone displacement and re-clustering) or to small submarine landslides cannot be excluded, these hypotheses could not be validated in the field. Detachment of portions of the appendicular skeleton before complete burial should also be considered, as suggested by the lack of bony elements of the left forelimb distal to the humerus.

The bones are very well preserved. The microscopic and microanalytical investigations indicate a good degree of mineralization of the bone tissue, now consisting of fluorapatite. Such a degree of mineralization suggests that the post-mortem degradation of collagen within bone tissues was followed, during the early stages of diagenesis, by recrystallization of the original hydroxylapatite, increase of crystallite size, and a consequent reduction of porosity (Trueman and Tuross, 2002; Keenan, 2016). The new Ca-phosphate phase, namely fluorapatite or carbonated fluorapatite (Pfretzschner, 2004; Wopenka and Pasteris, 2005), produced by recrystallization of bone hydroxylapatite has been demonstrated to be more stable, even in aqueous solutions at relatively low $\mathrm{pH}$ or low phosphorus concentrations (Keenan, 2016). Therefore, the presence of environmental conditions facilitating bone recrystallization during early diagenesis was a predominant parameter for the preservation of this beautiful specimen. 

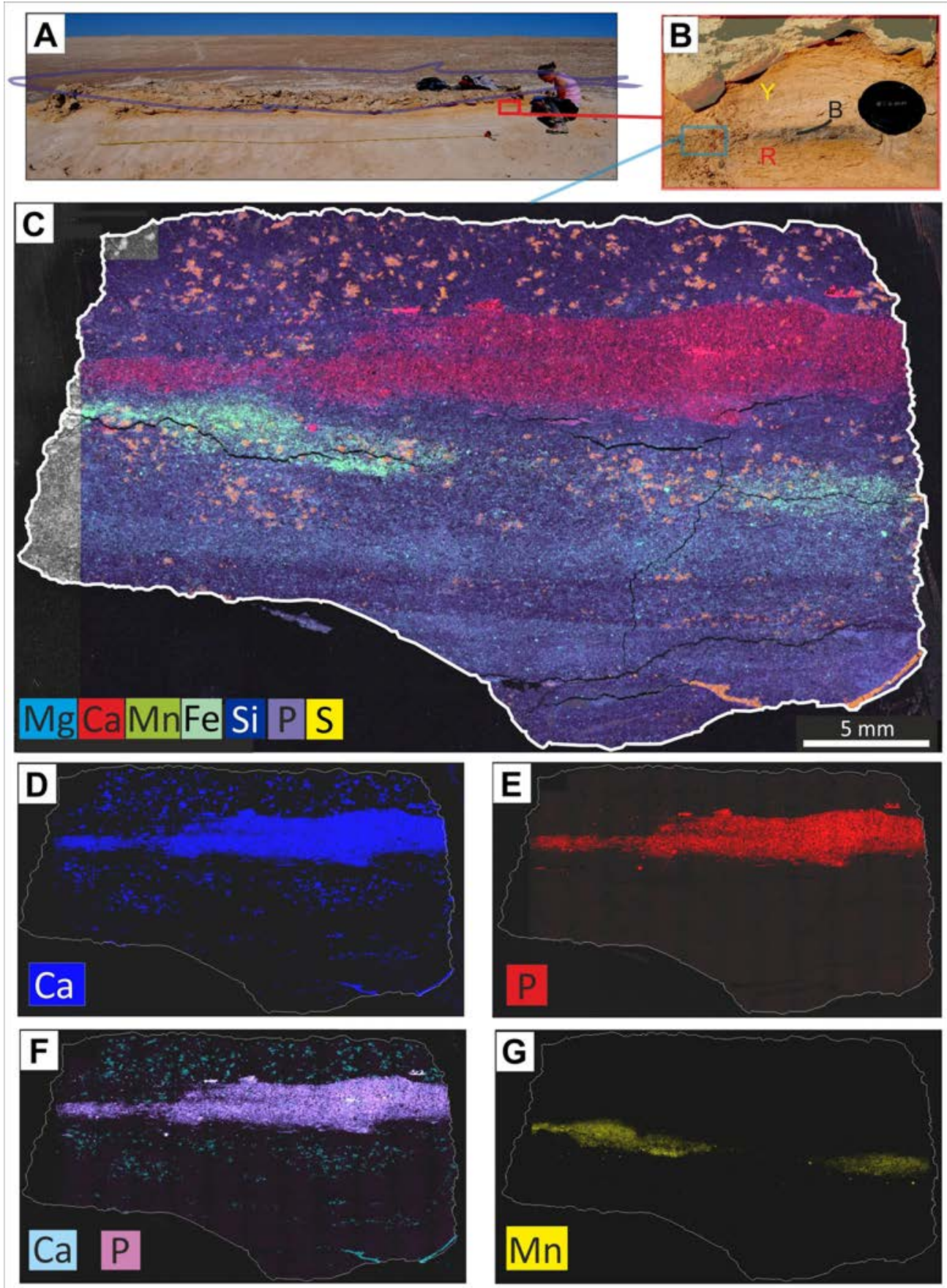

FIG. 5. Elemental maps of sediment below the fossil balaenopteroid whale CLQ-M58 at Cerro Los Quesos (location of specimen M58 in the map of the fossils of Cerro Los Quesos provided by Bianucci et al., 2016a). A. Specimen CLQ-M58 in the field, modified from Gariboldi et al. (2015). The red rectangle highlights the portion of sediment shown in B; B. Close up of the sediment underlying the fossil. The Mn layer is clearly visible (letter "B") and separates two portions of sediments characterized by two different colors, yellow (Y) and red (R). This pattern of sediment colors is often found below the fossil skeletons of the Pisco Fm. (Gariboldi et al., 2015); C. Composite elemental map of the yellow-black-red sequence underlying CLQ-M58, run on a polished mount of sediment embedded in resin and sectioned orthogonally to the strata; D. Ca elemental map; E. P elemental map; F. Ca and P composite elemental map (apatite); G. Mn elemental map. 


\subsection{The Mn-rich layer}

The evident Mn-rich layer around the specimen delimits a volume of sediment some centimeters away from the bones. Mn occurs also as patinae at the surface of the bones, but in this case it seems to follow infiltration paths, thus suggesting a late origin (see also Pfretzschner and Tütken, 2011). Associated to a high concentration of diagenetic Ca-phosphate (Fig. 3), the Mn-rich layer is unrelated to the late Mn patinae. Indeed, would it be a late feature, it would be difficult to explain the sharp boundary with the surrounding sediment, which remained permeable as indicated by the presence of late gypsum spots.

In the marine environment, $\mathrm{Mn}$ is soluble in the forms $\mathrm{Mn}^{2+}$ and $\mathrm{MnCl}^{+}$, whereas it forms oxide particulate as $\mathrm{Mn}(\mathrm{IV})$ in oxic waters (e.g., Calvert and Pedersen, 1993; Tribovillard et al., 2006). Mnrich layers may form by precipitation of Mn-minerals from seawater at a redox boundary, located below or at the sediment-water interface, as a consequence of the redox-dependent behavior of this element. The presence of reactive organic carbon at sea bottom or within sediment has a main role in governing the Mn reduction process. High concentrations of Fe may accompany Mn layers, due to the similarly redox-dependent behavior of this element. However, iron precipitation may not coincide with Mn layers since, differently from $\mathrm{Mn}$, it is possible in suboxic and in sulfidic conditions. Based on this framework, the preservation of manganese and iron layers in lacustrine and marine sediments can be studied to unravel early diagenetic processes (e.g., Burdige, 1993; Van Santvoort et al., 1996; De Lange et al., 2008; Torres et al., 2014; Löwemark et al., 2014).

The Mn layer below MUSM 887 seemingly encloses the fossil specimen (Fig. 2). Several similar examples, as that of specimen CLQ-M58 (see paragraph 3.5), have been observed in the field, suggesting the same relationship (Fig. 5). Therefore, it can be suggested that the formation or preservation of the Mn-cemented dark boundary is strictly related to the presence of the carcass: it delimits the volume of sediment that was affected by chemical conditions differing from the contemporary surrounding sea bottom as a consequence of the decay of the odontocete carcass.

The sedimentary palaeoenvironment of the highly fossiliferous sandstones that constitute the basal beds of the P2 sequence (i.e., the "Cerro La Bruja vertebrate level" exposed at Corre Viento) was a shallow-marine upper shelf environment (e.g., Di Celma et al., 2017) with an oxic water column and no evidence of anoxic conditions at the seafloor. Therefore, the oxidation front was located below the sediment-water interface, favoring the formation of a concentration of $\mathrm{Mn}$ in the upper sediment layer (Fig. 6A). We can suppose that, after the death of a marine vertebrate, aerobic remineralization of organic matter was the main, although not the sole, mechanism as long as the remains were exposed on the seafloor. In case of large-sized marine vertebrate falls, the oxygen recharge may be locally insufficient for organic matter oxidation, even if the conditions at the seafloor are generally oxic (Allison, 1988). Therefore, anaerobic reduction of $\mathrm{Mn}$, nitrate, and $\mathrm{Fe}$, as well as other biogeochemical processes such as sulfate reduction and methanogenesis, occur at the seafloor, governed by the microbial ecosystem of whale-falls (Allison et al., 1991; Shapiro and Spangler, 2009; Danise et al., 2012). These processes induce local geochemical gradients in the underlying sediments and in bones, e.g., in $\mathrm{pH}$, alkalinity, and sulfate/sulfide equilibrium (Treude et al., 2009). In the case of small-size marine vertebrates, such as the pontoporiid specimen MUSM 887, organic matter degradation on the seafloor may be accomplished mainly by aerobic processes. However, the early burial of MUSM 887 proposed to explain the arrangement of the preserved bones could have favored the above mentioned anaerobic biogeochemical processes, fueled by the organic matter (deriving from both soft tissues and bone lipids). In this locally oxygenpoor environment, the decay of organic matter could occur through biomediated processes of reduction of $\mathrm{Mn}$, nitrate, Fe, and sulfate. These processes can be fingerprinted by the consequent precipitation of specific authigenic minerals. As regards sulfate reduction, mineralogical evidence such as those found with the fossil vertebrates in dolomite nodules -relics of pyrite framboids and the dolomite itselfare absent in the MUSM 887 specimen. The Mn pattern, instead, may be interpreted in the frame of early diagenesis.

Mn may have rather high concentrations in seawater when the terrigenous input is high. In an oxic water column, it undergoes syn-sedimentary burial as Mn oxyhydroxide particulate (Tribovillard et al., 2006): the latter can be partly or completely reduced within the sediments below the oxic-anoxic boundary 
and then, with the upward migration of porewater, reprecipitated at the anoxic-oxic boundary, resulting in an upward migration of $\mathrm{Mn}$ that may or may not result in a local increase in Mn concentrations (Burdige, 1993). In the locally anoxic environment created by the decay of the Corre Viento cetacean carcass at the sea bottom, and in case of $\mathrm{Mn}$ availability within bottom sediment, Mn-reduction could have been one of the most prominent mechanisms for organic matter remineralization. Additionally, the lowering of $\mathrm{pH}$ due to bacterial decay of soft tissues favored Mn solubility. As a consequence, the increased Mn concentration in porewater resulted in the precipitation of Mn minerals at the anoxic-oxic interface and/or at an alkalinity interface, representing the boundary above which porewater was chemically affected by the processes of degradation of the carcass (Fig. 6B). Indeed, this Mn-rich layer would not have developed in case of deposition of the dolphin carcass on an anoxic sea bottom.
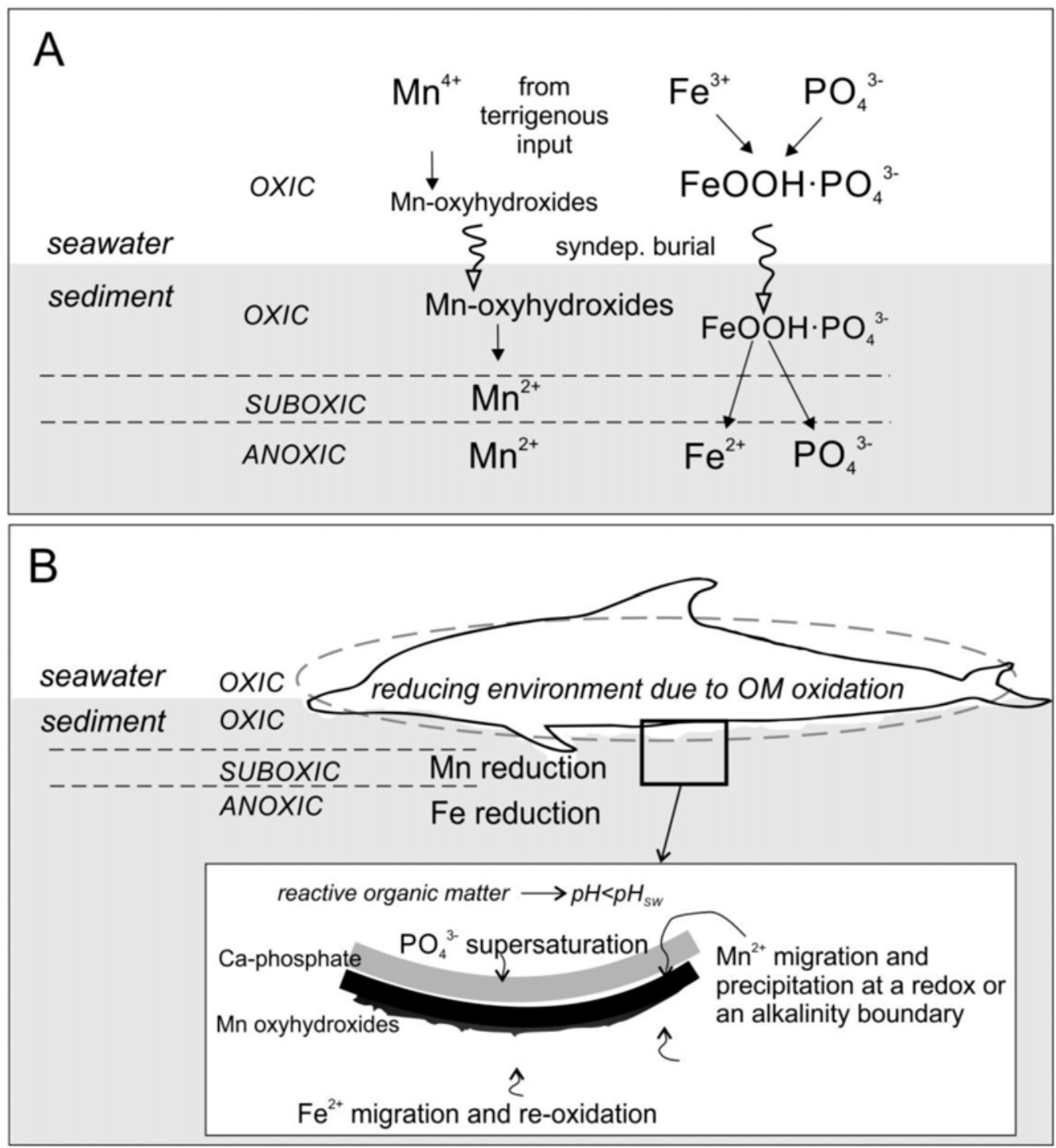

FIG. 6. A. Manganese, iron and phosphorus behavior at an oxic sea bottom (modified from Cui et al., 2016), OM: organic matter; B. Schematic model summarizing the hypothesized formation of the mineral pattern around the Corre Viento pontoporiid skeleton under study. 


\subsection{Insights from the presence of Ca-phosphate within sediment}

In the marine environment, phosphorus sourced by continental weathering is uptaken by microorganisms in the zone of primary productivity and incorporated into organic matter. Upon organic matter oxidation, dissolved inorganic phosphate is re-circulated by upwelling. The degradation of organic matter is, thus, a main source of P in marine sediments (Föllmi, 1996; Filippelli, 2008; Cosmidis et al., 2013). With an oxic water column and in conditions of high primary productivity such as those of the Corre Viento shelf depositional environment, dissolved phosphate is vehiculated to the seafloor together with $\mathrm{Fe}^{3+}$ (as $\left.\mathrm{FeOOH} \cdot \mathrm{PO}^{3-}\right)$ and is then released to the porewater following Fe-reduction in anoxic conditions below the water-sediment interface (Kim et al., 1999; Cui et al., 2016). In the case of the studied pontoporiid, anoxic conditions were induced in correspondence of the carcass by decay processes. Consequently, $\mathrm{Fe}-$ reduction processes and, possibly, the decay of the carcass itself, released $\mathrm{P}$ increasing its concentration in porewater close to the pontoporiid remains, inducing authigenic calcium phosphate precipitation at the boundary with suboxic conditions (Fig. 6). The slight lowering of $\mathrm{pH}$ relative to normal seawater that is necessary to stabilize calcium phosphate with respect to carbonate could have been accomplished by the bacterial decay of soft tissues (Briggs and Kear, 1993; Dornbos, 2011).

The presence of Ca-phosphate immediately below the specimen is, thus, an evidence of availability of $\mathrm{P}$ in porewater during the very early diagenesis: this is a factor of prime importance for bone apatite recrystallization and, consequently, for preservation (Keenan, 2016; Keenan and Engel, 2017). Therefore, the geochemical environment in which the pontoporiid was set once the labile tissues were decayed (probably on a timescale of weeks) can explain the high degree of mineralization observed for the compact bone of the pontoporiid ribs.

The sediment hosting the pontoporiid does not present evidence of a phosphogenic depositional environment, although the above mechanisms are similar to those suggested to explain phosphogenesis along the Peruvian margin (Arning et al., 2009). Accordingly, the specimen does not present borings and phosphatization crusts on the bones and evidence of microbially mediated sulfate-reduction processes such as pyrite relics. Based on the above reported evidences, we suggest that the pontoporiid cetacean carcass was partially buried in permeable sediments soon after death, prior to the decay of most of the soft tissues. This scenario is in agreement with the degree of articulation and completeness of the specimen, and allowed the establishment of a local anoxic/ suboxic micro-environment within a generally oxic sea bottom, which in turn explains the development of the observed patterns of apatite and Mn-oxide authigenic minerals.

\subsection{Preservation of fossil vertebrates with and without concretion}

Differently from several specimens in the Pisco Formation, in the case here studied, the fossil is not enclosed in a dolomite concretion.

Dolomite formation is inhibited by the high dissolved sulfate ion concentration in seawater (Baker and Kastner, 1981). The microbially mediated sulfate reduction is able to lower the sulfate ion inhibitory effect and, concomitantly, increases alkalinity (e.g., Compton, 1988). In agreement with the lack of dolomite, we did not find evidence of former pyrite framboids, typically a result of sulfate reduction, associated to the bones. We speculate that the Corre Viento sandy sediments allowed the porewater below the water-sediment interface to exchange with seawater in a rather efficient way. Therefore, even with sulfate reduction, the moderate permeability of the sediment enclosing the pontoporiid carcass, coupled with the small body size of the specimen, would have prevented the concentration of dissolved sulfate (inhibiting dolomite formation) to decrease enough (or for long enough) for allowing extensive dolomite formation (Vasconcelos et al., 1995; Meister, 2013).

Interestingly, the neurocranium of MUSM 887 is well preserved and barely deformed (Fig. 2). This could be explained by hypothesizing that the inside of the brain cavity is filled by early-formed diagenetic minerals, very likely dolomite, as it is commonly observed in fossil vertebrates of the Pisco Formation, including small-sized animals (Gariboldi et al., 2015; Gioncada et al., 2016; and field observations of numerous dolomite-filled inner casts of brain cavities). Should it be confirmed (by non-invasive methods such as microdrilling), the specimen could be regarded as an example of partial 
concretion. The formation of early dolomite could be explained by the fact that the inside of the brain cavity is an environment with abundant organic matter (mostly consisting of easily degradable lipids) and at the same time protected from exchanges with seawater-a combination of factors that facilitates sulfate reduction and the establishment of local conditions favorable to precipitation of carbonate, even before the complete burial of the skeleton.

As mentioned above, several dolomite concretions of the Pisco Formation are delimited by a dark Mnrich boundary. The SEM elemental maps in figure 5 indicate that, also in the case of the balaenopteroid specimen M58, this boundary consists of a subtle layer permeated by Mn minerals and overlain by a layer with abundant authigenic apatite. This observation strongly suggests that the same pattern of diagenetic minerals found close to the pontoporiid specimen MUSM 887 studied in this work also developed around specimen M58, most likely as a result of similar biogeochemical processes related to the decaying organic matter. Varying development of the Mn layer in these two specimens is probably due to different environmental availability of $\mathrm{Mn}$ at the two sites.

The lack of dolomite in the sediment enclosing MUSM 887 suggests that the fall of this small-sized cetacean carcass did not induce a local variation of the chemical environment intense enough to reach conditions favorable to the formation of a carbonate concretion. As already suggested elsewhere (Gariboldi et al., 2015), this record identifies the amount of decaying organic matter - directly related to the body size of the dead animal - as one of the most prominent factors controlling the development of concretions linked to altered chemical environments surrounding marine vertebrate carcasses lying on the seafloor. Thanks to embedding in a relatively permeable sediment devoid of any dolomite nodule and to the availability of $\mathrm{P}$, the recrystallization of bone apatite was favored, allowing excellent bone tissue preservation. Therefore, the taphonomic scenario proposed in the present work contributes to bridge two emblematic modes of preservation of the fossil marine vertebrates of the Pisco Formation: i) preservation outside any nodule or concretion, sometimes exhibiting prominent phosphatization of the vertebrate remains (e.g., Marx et al., 2017), and ii) preservation within a fully developed, hard, and impermeable dolomite concretion (e.g., Gariboldi et al., 2015; Gioncada et al., 2016) with modest bone mineralization. More generally, different patterns in the formation of diagenetic minerals can be expected, depending on factors such as the time between death and burial, the oxygen level at the sea bottom, permeability and composition of the sediment, and the amount of soft tissues and bone lipids available for decay. Interpreting these different patterns may provide significant insights into the early fossilization history of well-preserved fossil vertebrates.

\section{Conclusions}

A partial skeleton referred to the extinct small dolphin species Brachydelphis mazeasi (Pontoporiidae) has been described from the late Miocene site of Pampa Corre Viento (Pisco Formation, southern Peru), and microscopical and microanalytical investigations were undertaken both on it and on the surrounding sediment. The overall excellent preservation state of the cetacean specimen and remarkable articulation degree suggest that it was buried soon after death.

Early diagenetic processes triggered by the anaerobically degrading cetacean carcass are revealed by the types and patterns of diagenetic minerals found around the pontoporiid skeleton. Conditions favorable to precipitation of calcium phosphate, but not dolomite, around the specimen allowed increased mineralization of the bones. The presence of a dolomite nodule may be hypothesized inside the brain cavity, preventing its deformation under lithostatic pressure.

As a general consideration, the observation of regular and recurrent patterns for the distribution of diagenetic minerals in the sediment enclosing fossil vertebrates, without or with limited carbonate concretions, gives insights into the early taphonomic history of these remains, just as dolomite concretions do. In the case of the pontoporiid skeleton here investigated, this pattern reveals a situation favorable to preservation, with early burial and the establishment of local anoxic/suboxic porewater environment, even if the surrounding seafloor environment and water column were characterized by fully oxic conditions.

\section{Acknowledgements}

R. Varas-Malca and W. Aguirre are thanked for assisting the work at Museo de Historia Natural de la Universidad Nacional Mayor de San Marcos in Lima. The authors are grateful to F. Colarieti (University of 
Pisa), M. Serracino (CNR, Rome) and to A. Oldroy and D. Muir (School of Earth and Ocean Sciences, University of Cardiff) for their experienced help with analytical work. V.M. Gamboa Sojo is gratefully thanked for help with the Spanish translation of abstract and title. Reviews by G. Carnevale and C.H. Tsai are gratefully acknowledged. Funded by University of Pisa PRA_2015_0028 grant, the University of Pisa PRA_2017_0032 grant and by PRIN (Progetti di Ricerca di Interesse Nazionale) Project 2012YJSBMK EAR-9317031.

\section{References}

Allison, P.A. 1988. The decay and mineralization of proteinaceous macrofossils. Paleobiology 14: 139-154.

Allison, P.A.; Smith, C.R.; Kukert, H.; Deming, J.W.; Bennett, B.A. 1991. Deep-water taphonomy of vertebrate carcasses: a whale skeleton in the bathyal Santa Catalina Basin. Paleobiology 17: 78-89.

Arning, E.T.; Birgel, D.; Brunner, B.; Peckmann, J. 2009. Bacterial formation of phosphatic laminites of Peru. Geobiology 7: 295-307.

Baker, P.A.; Kastner, M. 1981. Constraints on the formation of sedimentary dolomite. Science 213 (4504): 214-216.

Bianucci, G.; Di Celma, C.; Collareta, A.; Landini, W.; Post, K.; Tinelli, C.; De Muizon, C.; Bosio, G.; Gariboldi, K.; Gioncada, A.; Malinverno, E.; Cantalamessa, G.; Altamirano-Sierra, A.; Salas-Gismondi, R.; Urbina, M.; Lambert, O. 2016a. Fossil marine vertebrates of Cerro Los Quesos: Distribution of cetaceans, seals, crocodiles, seabirds, sharks, and bony fish in a late Miocene locality of the Pisco Basin, Peru. Journal of Maps 12 (5): 1037-1046.

Bianucci, G.; Di Celma, C.; Landini, W.; Post, K.; Tinelli, C.; De Muizon, C.; Gariboldi, K.; Malinverno, E.; Cantalamessa, G.; Gioncada, A.; Collareta, A.; SalasGismondi, R.; Varas, R.; Stucchi, M.; Urbina, M.; Lambert, O. 2016b. Distribution of fossil marine vertebrates in Cerro Colorado, the type locality of the giant raptorial sperm whale Livyatan melvillei (Miocene, Pisco Formation, Peru). Journal of Maps 12 (3): 543-557.

Bisconti, M. 2012. Comparative osteology and phylogenetic relationships of Miocaperea pulchra, the first fossil pygmy right whale genus and species (Cetacea, Mysticeti, Neobalaenidae): Zoological Journal of the Linnean Society 166 (4): 876-911.

Brand, L.R.; Esperante, R.; Chadwick, A.V.; Poma Porras, O.; Alomía, M. 2004. Fossil whale preservation implies high diatom accumulation rate in the Miocene-Pliocene Pisco Formation of Peru. Geology 32: 165-168.

Briggs, D.E.G.; Kear, A.J. 1993. Fossilization of soft tissue in the laboratory. Science 259: 1439-1442.

Burdige, D.J. 1993. The biogeochemistry of manganese and iron reduction in marine sediments. Earth-Science Reviews 35: 249-284.

Calvert, S.E.; Pedersen, T.F. 1993. Geochemistry of recent oxic and anoxic marine sediments: implications for the geological record. Marine Geology 113 (1): 67-88.

Clift, P.D.; Pecher, I.; Kukowski, N.; Hampel, A. 2003. Tectonic erosion of the Peruvian forearc, Lima Basin, by subduction and Nazca Ridge collision. Tectonics 22 (3): 1023. doi: 10.1029/2002TC001386.

Collareta, A.; Landini, W.; Lambert, O.; Post, K.; Tinelli, C.; Di Celma, C.; Panetta, D.; Tripodi, M.; Salvadori, P.A.; Caramella, D.; Marchi, D.; Urbina, M.; Bianucci, G. 2015. Piscivory in a Miocene Cetotheriidae of Peru: first record of fossilized stomach content for an extinct baleen-bearing whale. The Science of Nature 102: 70 . doi: 10.1007/s00114-015-1319-y.

Collareta, A.; Landini, W.; Chacaltana, C.; Valdivia, W.; Altamirano-Sierra, A.; Urbina, M.; Bianucci, G. 2017. A well preserved skeleton of the fossil shark Cosmopolitodus hastalis from the late Miocene of Peru, featuring fish remains as fossilized stomach contents. Rivista Italiana di Paleontologia e Stratigrafia 123 (1): 11-22.

Compton, J.S. 1988. Degree of supersaturation and precipitation of organogenic dolomite. Geology 16 (4): 318-321.

Cosmidis, J.; Benzerara, K.; Menguy, N.; Arning, E. 2013. Microscopy evidence of bacterial microfossils in phosphorite crusts of the Peruvian shelf: Implications for phosphogenesis mechanisms. Chemical Geology 359: 10-22.

Cui, H.; Xiao, S.; Zhou, C.; Penge, Y.; Kaufman, A.J.; Plummer, R.E. 2016. Phosphogenesis associated with the Shuram Excursion: Petrographic and geochemical observations from the Ediacaran Doushantuo Formation of South China. Sedimentary Geology 341: 134-146.

Danise, S.; Cavalazzi, B.; Dominici, S.; Westall, F.; Monechi, S.; Guioli, S. 2012. Evidence of microbial activity from a shallow water whale fall (Voghera, northern Italy). Palaeogeography, Palaeoclimatology, Palaeoecology 317-318: 13-26. doi: 10.1016/j.palaeo.2011.12.001.

De Lange, G.J.; Thomson, J.; Reitz, A.; Slomp, C.P.; Principato, S.; Erba, E.; Corselli, C. 2008. Synchronous basin-wide formation and redox-controlled preservation of a Mediterranean sapropel. Nature Geoscience 1: 606-610. doi: 10.1038/ngeo283. 
De Muizon, C. 1988. Les vertebrés fossiles de la Formation Pisco (Pérou). Troisième partie: Les Odontocètes (Cetacea, Mammalia) du Miocène. Institut Français d'Études Andines: 244 p. Paris.

De Muizon, C.; DeVries, T.J. 1985. Geology and paleontology of late Cenozoic marine deposits in the Sacaco area (Peru), Geologische Rundschau 74 (3): 547-563.

DeVries, T.J. 1998. Oligocene deposition and Cenozoic sequence boundaries in the Pisco Basin (Peru). Journal of South American Earth Sciences 11: 217-231.

Di Celma, C.; Malinverno, E.; Cantalamessa, G.; Gioncada,A.; Bosio, G.; Villa, I.M.; Gariboldi, K.; Rustichelli, A.; Pierantoni, P.P.; Landini, W.; Tinelli, C.; Collareta, A.; Bianucci, G. 2016a. Stratigraphic framework of the late Miocene Pisco Formation at Cerro Los Quesos (Ica Desert, Peru). Journal of Maps 12 (5): 1020-1028. doi: 10.1080/17445647.2015.1115783.

Di Celma, C.; Malinverno, E.; Gariboldi, K.; Gioncada, A.; Rustichelli, A.; Pierantoni, P.P.; Landini, W.; Bosio, G.; Tinelli, C.; Bianucci, G. 2016b. Stratigraphic framework of the late Miocene to Pliocene Pisco Formation at Cerro Colorado (Ica Desert, Peru). Journal of Maps 12 (3): 515-529. doi: 10.1080/17445647.2015.1047906.

Di Celma, C.; Malinverno, E.; Bosio, G.; Collareta, A.; Gariboldi, K.; Gioncada, A.; Molli, G.; Basso, D.; VarasMalca, R.; Pierantoni, P.P.; Villa, I.M.; Lambert, O.; Landini, W.; Sarti, G.; Cantalamessa, G.; Urbina, M.; Bianucci, G. 2017. Sequence stratigraphy and paleontology of the upper Miocene Pisco Formation along the western side of the lower Ica Valley (Ica Desert, Peru). Rivista Italiana di Paleontologia e Stratigrafia 123 (2): 255-273.

Di Celma, C.; Malinverno, E.; Bosio, G.; Gariboldi, K.; Collareta, A.; Gioncada, A.; Landini, W.; Pierantoni, P.P.; Bianucci, G. 2018a. Intraformational unconformities as a record of late Miocene eustatic falls of sea level in the Pisco Formation (southern Peru). Journal of Maps. doi: 10.1080/17445647.2018.1517701.

Di Celma, C.; Malinverno, E.; Collareta, A.; Bosio, G.; Gariboldi, K.; Lambert, O.; Landini, W.; Pierantoni, P.P.; Gioncada, A.; Villa, I.M.; Coletti, G.; De Muizon, C.; Urbina, M.; Bianucci, G. 2018b. Facies analysis, stratigraphy and marine vertebrate assemblage of the lower Miocene Chilcatay Formation at Ullujaya (Pisco basin, Peru). Journal of Maps 14 (2): 257-268. doi: 10.1080/17445647.2018.1456490.

Dornbos, S.Q. 2011. Phosphatization through the Phanerozoic. In Taphonomy: Process and Bias through Time (Allison, P.A.; Bottjer, D.J.; editors). Springer: 435-456. doi: 10.1007/978-90-481-8643-3.
Dunbar, R.B.; Marty, R.C.; Baker, P.A. 1990. Cenozoic marine sedimentation in the Sechura and Pisco basins, Peru. Palaeogeography, Palaeoclimatology, Palaeoecology 77: 235-261.

Ehret, D.J.; Hubbell, G.; MacFadden, B.J. 2009. Exceptional preservation of the white shark Carcharodon (Lamniformes, Lamnidae) from the early Pliocene of Peru. Journal of Vertebrate Paleontology 29 (1): 1-13.

Ehret, D.J.; Macfadden, B.J.; Jones, D.S.; Devries, T.J.; Foster, D.A.; Salas-Gismondi, R. 2012. Origin of the white shark Carcharodon (Lamniformes: Lamnidae) based on recalibration of the upper Neogene Pisco Formation of Peru. Palaeontology 55 (6): 1139-1153.

Esperante, R.; Brand, L.; Nick, K.; Poma, O.; Urbina, M. 2008. Exceptional occurrence of fossil baleen in shallow marine sediments of the Neogene Pisco Formation, Southern Peru. Palaeogeography, Palaeoclimatology, Palaeoecology 257: 344-360.

Esperante, R.; Brand, L.R.; Chadwick, A.V.; Poma-Porras, O. 2015. Taphonomy and paleoenvironmental conditions of deposition of fossil whales in the diatomaceous sediments of the Miocene/Pliocene Pisco Formation, southern Peru-a new Fossil-lagerstätte. Palaeogeography, Palaeoclimatology, Palaeoecology 417: 337-370.

Filippelli, G.M. 2008. The global phosphorus cycle: past, present, and future. Elements 4: 89-95.

Föllmi, K.B. 1996. The phosphorus cycle, phosphogenesis and marine phosphate-rich deposits. Earth-Science Reviews 40 (1-2): 55-124.

Gariboldi, K.; Gioncada, A.; Bosio, G.; Malinverno, E.; Di Celma, C.; Tinelli, C.; Cantalamessa, G.; Landini, W.; Urbina, M.; Bianucci, G. 2015. The dolomite nodules enclosing fossil marine vertebrates in the East Pisco Basin, Peru: field and petrographic insights into their genesis and role in preservation. Palaeogeography, Palaeoclimatology, Palaeoecology 438: 81-95.

Gariboldi, K.; Bosio, G.; Malinverno, E.; Gioncada, A.; Di Celma, C.; Villa, I.M.; Urbina, M.; Bianucci, G. 2017. Biostratigraphy, geochronology and sedimentation rates of the upper Miocene Pisco Formation at two important marine vertebrate fossil-bearing sites of southern Peru. Newsletters on Stratigraphy 50 (4): 417-444.

Gioncada, A.; Collareta, A.; Gariboldi, K.; Lambert, O.; Di Celma, C.; Bonaccorsi, E.; Urbina, M.; Bianucci, G. 2016. Inside baleen: Exceptional microstructure preservation in a late Miocene whale skeleton from Peru. Geology 44 (10): 839-842.

Gioncada,A.; Petrini, R.; Bosio, G.; Gariboldi, K.; Collareta,A.; Malinverno, E.; Bonaccorsi, E.; Di Celma, C.; Pasero, M.; 
Urbina, M.; Bianucci, G. 2018. Insights into the diagenetic environment of fossil marine vertebrates of the Pisco Formation (late Miocene, Peru) from mineralogical and Sr-isotope data. Journal of South American Earth Sciences 81: 141-152.

Gutstein, C.S.; Yury-Yáñez, R.E.; Soto-Acuña, S.; Suárez, M.E.; Rubilar-Rogers, D. 2008. Fauna de vertebrados y aspectos tafonómicos del "bonebed" (Mioceno tardío) de la Formación Bahía Inglesa. In Simposio Paleontología en Chile, No. 1. Libro de Actas: 102-108. Santiago.

Gutstein, C.S.; Cozzuol, M.A.; Vargas, A.O.; Suárez, M.E.; Schultz, C.L.; Rubilar-Rogers, D. 2009. Patterns of skull variation of Brachydelphis (Cetacea, Odontoceti) from the Neogene of the Southeastern Pacific. Journal of Mammalogy 90 (2): 504-519.

Hampel, A.; Adam, J.; Kukowski, N. 2004. Response of the tectonically erosive south Peruvian forearc to subduction of the Nazca Ridge: Analysis of three dimensional analogue experiments, Tectonics 23: TC5003. doi: 10.1029/2003TC001585.

Keenan, S.W. 2016. From bone to fossil: A review of the diagenesis of bioapatite. American Mineralogist 101: 1943-1951.

Keenan, S.W.; Engel, A.S. 2017. Early diagenesis and recrystallization of bone. Geochimica et Cosmochimica Acta 196: 209-223.

Kim, D.; Schuffert, J.D.; Kastner, M. 1999. Francolite authigenesis in California continental slope sediments and its implications for the marine P cycle. Geochimica et Cosmochimica Acta 63 (19-20): 3477-3485.

Kulm, L.D.; Resig, J.M.; Thornburg, T.M.; Schrader, H.J. 1982. Cenozoic structure, stratigraphy and tectonics of the central Peru forearc. In Trench and Forearc Geology: Sedimentation and Tectonics on Modern and Ancient Plate Margins (Legget, J.K.; editor). Geological Society, London, Special Publications 10 (1): 151-169. London. doi: 10.1144/GSL.SP.1982.010.01.10.

Lambert, O.; Post, K. 2005. First European pontoporiid dolphins (Mammalia: Cetacea, Odontoceti) from the Miocene of Belgium and the Netherlands. Deinsea 11: 7-20.

Lambert, O.; De Muizon, C. 2013. A new longsnouted species of the Miocene pontoporiid dolphin Brachydelphis and a review of the Mio-Pliocene marine mammal levels in the Sacaco Basin, Peru. Journal of Vertebrate Paleontology 33 (3): 709-721. doi: 10.1080/02724634.2013.743405.

Lambert, O.; Collareta, A.; Landini, W.; Post, K.; Ramassamy, B.; Di Celma, C.; Urbina, M.; Bianucci, G.
2015. No deep diving: evidence of predation on epipelagic fish for a stem beaked whale from the late Miocene of Peru. Proceedings of the Royal Society B, Biological Sciences 282: 20151530. doi: 10.1098/ rspb.2015.1530.

León, W.; Aleman, A.; Rosell, W.; Torres, V.; De la Cruz, O. 2008. Estratigrafía, Sedimentologia y Evolución Tectónica de la Cuenca Pisco Oriental. Dirección de Geología Regional, Instituto Geológico Minero y Metalúrgico (INGEMMET). Boletín 27, Serie D: Estudios Regionales: 161 p. Lima.

Löwemark, L.; März, C.; O’Regan, M.; Gyllencreutz, R. 2014. Arctic Ocean Mn-stratigraphy: genesis, synthesis and inter-basin correlation. Quaternary Science Reviews 92: 97-111.

Marx, F.G.; Collareta, A.; Gioncada, A.; Post, K.; Lambert, O.; Bonaccorsi, E.; Urbina, M.; Bianucci, G. 2017. How whales used to filter: exceptionally preserved baleen in a Miocene cetotheriid. Journal of Anatomy 231 (2): 212-220.

Marx, F.G.; Kohno, N. 2016. A new Miocene baleen whale from the Peruvian desert. Royal Society Open Science 3 (10): 160542. doi: 10.1098/rsos.160542.

McCoy, V.E.; Young, R.T.; Briggs, D.E.G. 2015. Sediment permeability and the preservation of soft-tissues in concretions: An experimental study. Palaios 30: 608-612.

Meister, P. 2013. Two opposing effects of sulfate reduction on carbonate precipitation in normal marine, hypersaline, and alkaline environments. Geology 41 (4): 499-502.

Pfretzschner, H.U. 2004. Fossilization of Haversian bone in aquatic environments. Comptes Rendus Palevol 3: 605-616.

Pfretzschner, H.U.; Tütken, T. 2011. Rolling bonesTaphonomy of Jurassic dinosaur bones inferred from diagenetic microcracks and mineral in fillings. Palaeogeography, Palaeoclimatology, Palaeoecology 310 (1-2): 117-123.

Pilleri, G.; Pilleri, O. 1989. Balaenoptera siberi, ein neuer balaenopterid (Cetacea) aus der Pisco-Formation Perus. In Beitrage zur Palaeontologie der Cetaceen Perus I (Pilleri, G.; editor). Hirnanatomisches Institut der Universitat Bern Ostermundigen: 63-106. Bern.

Reisdorf, A.G.; Bux, R.; Wyler, D.; Benecke, M.; Klug, C.; Maisch, M.W.; Fornaro, P.; Wetzel, A. 2012. Float, explode or sink: postmortem fate of lung-breathing marine vertebrates. Palaeobiodiversity and Palaeoenvironments 92 (1): 67-81. 
Reisdorf, A.G.; Anderson, G.S.; Bell, L.S.; Klug, C.; Schmid-Röhl, A.; Röhl, H.J.; Jung, M.; Wuttke, M.; Maisch, M.W.; Benecke, M.; Wyler, D.; Bux, R.; Fornaro, P.; Wetzel, A. 2014. Reply to "Ichthyosaur embryos outside the mother body: not due to carcass explosion but to carcass implosion" by van Loon (2013). Palaeobiodiversity and Palaeoenvironments 94 (3): 487-494.

Shapiro, R.S.; Spangler, E. 2009. Bacterial fossil record in whale-falls: petrographic evidence of microbial sulfate reduction. Palaeogeography, Palaeoclimatology, Palaeoecology 274: 196-203.

Thornburg, T.M.; Kulm, L.D. 1981. Sedimentary basins of the Peru continental margin: structure, stratigraphy, and Cenozoic tectonics from $6^{\circ} \mathrm{S}$ to $16^{\circ} \mathrm{S}$ latitude. In Nazca plate: crustal formation and Andean convergence (Kulm, L.D.; Dymond, J.; Dasch, E.J.; Hussong, D.M.; editors). Geological Society of America, Memoir 154: 393-422.

Torres, N.T.; Och, L.M.; Hauser, P.C.; Furrer, G.; Brandl, H.; Vologina, E.; Sturm, H.; Burgmann, H.; Muller, B. 2014. Early diagenetic processes generate iron and manganese oxide layers in the sediments of Lake Baikal, Siberia. Environmental Sciences Processes Impacts 16 (4): 879-889. doi: 10.1039/c3em00676j.

Treude, T.; Smith, C.R.; Wenzhöfer, F.; Carney, E.; Bernardino, A.; Hannides, A.K.; Krüger, M.; Boetius, A. 2009. Biogeochemistry of a deep-sea whale fall: sulfate reduction, sulfide efflux and methanogenesis. Marine Ecology Progress Series 382: 1-21.
Tribovillard, N.; Algeo, T.J.; Lyons, T.; Riboulleau, A. 2006. Trace metals as paleoredox and paleoproductivity proxies: an update. Chemical Geology 232 (1): 12-32.

Trueman, C.N.; Tuross, N. 2002. Trace elements in recent and fossil bone apatite. Reviews in Mineralogy and Geochemistry 48: 13-49.

Van Santvoort, P.J.M.; de Lange, G.J.; Thomson, J.; Cussen, H.; Wilson, T.R.S.; Krom, M.D.; Ströhle, K. 1996. Active post-depositional oxidation of the most recent sapropel (S1) in sediments of the eastern Mediterranean Sea. Geochimica et Cosmochimica Acta 60: 4007-4024.

Vasconcelos, C.; McKenzie, J.A.; Bernasconi, S.; Grujic, D.; Tien, A.J. 1995. Microbial mediation as a possible mechanism for natural dolomite formation at low temperatures. Nature 377: 220-222.

Wopenka, B.; Pasteris, J.D. 2005. A mineralogical perspective on the apatite in bone. Materials Science and Engineering C 25: 131-143.

Yoshida, H.; Ujihara, A.; Minami, M.; Asahara, Y.; Katsuta, N.; Yamamoto, K.; Sirono, S.; Maruyama, I.; Nishimoto, S.; Metcalfe, R. 2015. Early post-mortem formation of carbonate concretions around tusk-shells over week-month timescales. Scientific Reports 5: 14123. doi: $10.1038 /$ srep 14123 .

Zúñiga-Rivero, F.J.; Klein, G.D.; Hay-Roe, H.; Álvarez-Calderón, E. 2010. The hydrocarbon potential of Peru. BPZ Exploración and Producción S.R.L.: 338 p. Lima.

Manuscript received: October 25, 2017; revised/accepted: May 15, 2018; available online: May 31, 2018. 


\section{Appendix}

\section{Analytical methods}

Small fragments of the rib bone and of the enclosing rock were taken from MUSM 887 for analysis, in the minimum necessary amount.

Three fragments of the cortical bone of the rib and a piece of the enclosing sediment including the dark layer were mounted in resin, polished and examined in reflected light optical microscopy, then carbon-coated for SEM-EDS and EPMA analysis. SEM-EDS analysis (scanning electron microscopy by secondary and back-scattered electrons imaging and EDS microanalysis) was carried out by means of a Philips XL30 SEM equipped with a Dx4i microanalytical device at the Earth science Department of Pisa University, using $20 \mathrm{kV}$ filament voltage, $5 \mathrm{nA}$ beam current, ZAF correction and $100 \mathrm{~s}$ point counting. EPMA (electron probe microanalysis by wavelength-dispersive spectroscopy was carried out with a Cameca SX50 instrument at CNR, Rome, Italy, using a defocused beam of 10 microns.

XRPD was carried out on the rock sediment above, below and in correspondence of the dark layer, with a Philips diffractometer at the Earth Science Department of Pisa University. XRPD analyses were carried out after pulverization in an agate mortar.

Analysis on the sediment hosting specimen CLQ-M58 (Cerro Los Quesos, Pisco desert; see Gariboldi et al., 2015 and Bianucci et al., 2016b for specimen characteristics and location) were run to compare the results with those obtained for the sediment enclosing MUSM 887. The sedimentary rock enclosing CLQ-M58 was cut into small blocks (a few $\mathrm{cm}^{3}$ blocks) and then embedded in epoxy resin using a vacuum chamber. Impregnated blocks were glued to a microscope slide, cut with a saw, grinded and polished. Elemental maps of one of the obtained slide were run at the School of Earth and Ocean Science, Cardiff University, by means of a Zeiss Sigma HD Field Emission Gun Analytical SEM (ASEM) equipped with a $\mu$ XRF. The sample was mapped with a $50 \mu \mathrm{m}$ pixel size, $200 \times 189$ resolution and a $25 \mathrm{~ms}$ point dwell time. The results were displayed on compositional maps using different colors for different elements.

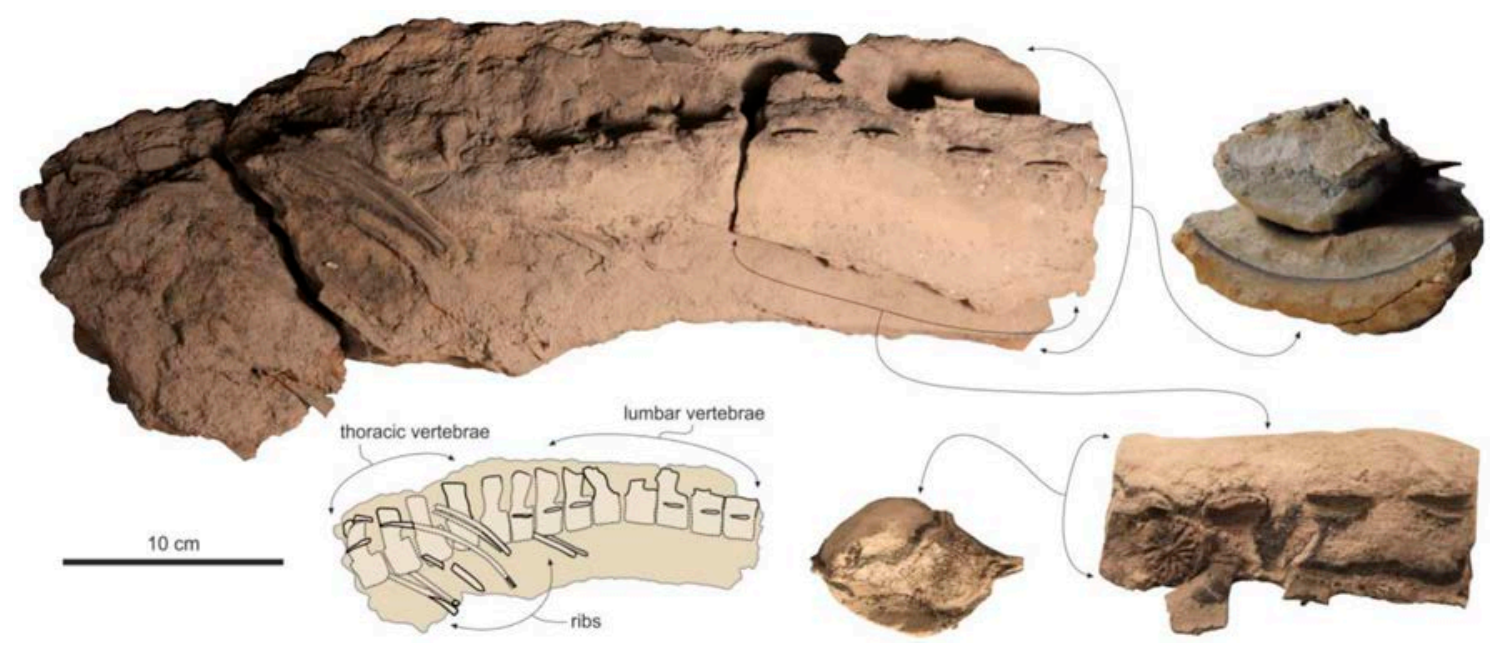

FIG. 1. The block containing several articulated lumbar to caudal vertebrae of the small dolphin Brachydelphis mazeasi MUSM 887, with corresponding line drawing indicating the different elements preserved. 


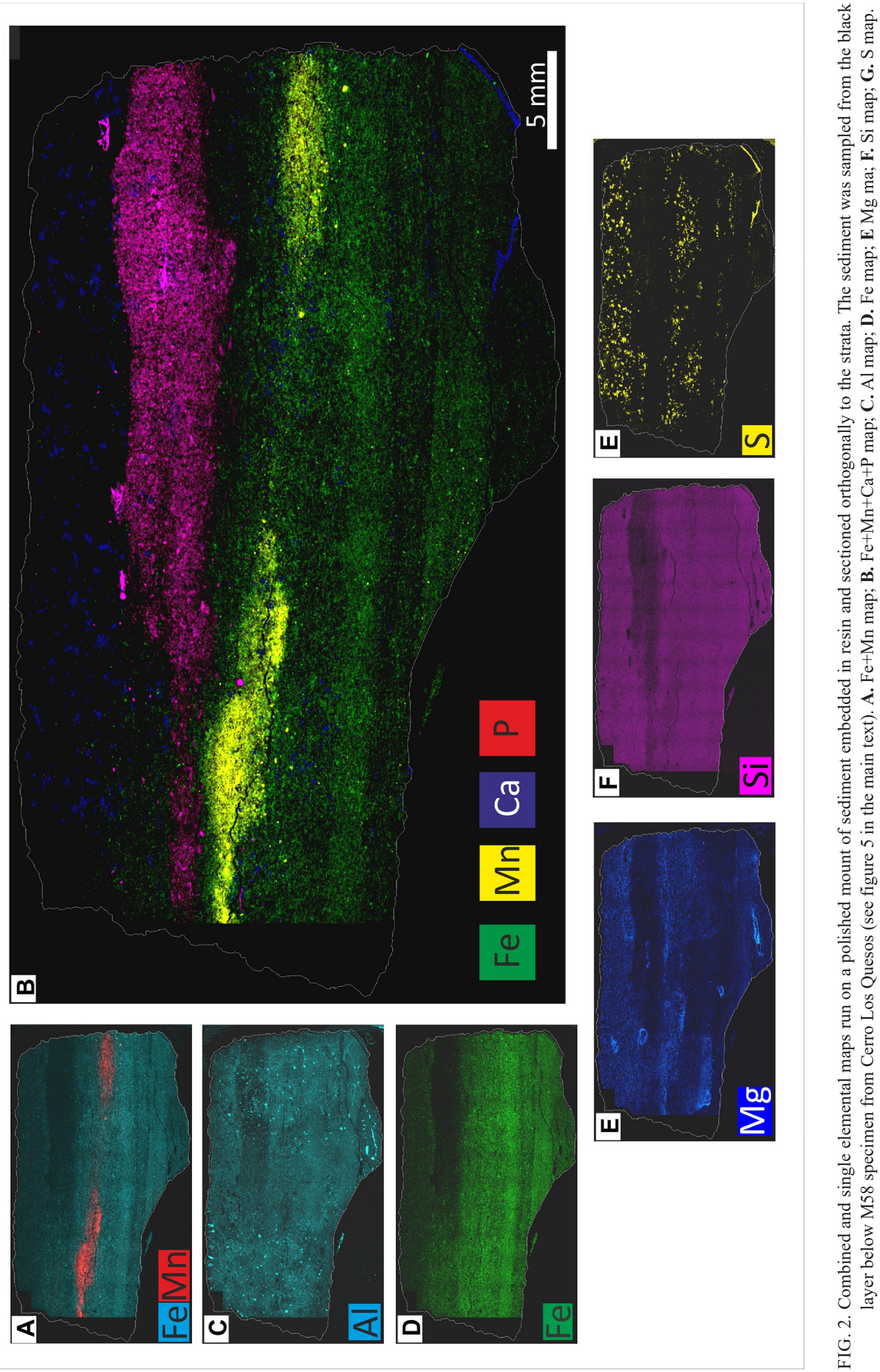

